\title{
Decision Making under Uncertainty in Agriculture-A Case Study
}

\author{
P. Lavanya Kumari ${ }^{1 *}$ and P. Maheswara Reddy ${ }^{2}$ \\ ${ }^{1}$ Department of Statistics and Computer Applications, S.V. Agricultural College, \\ ${ }^{2}$ Department of Agronomy, Regional Agricultural Research Station \\ ANGRAU, Tirupati, Andhra Pradesh, India \\ *Corresponding author
}

\section{A B S T R A C T}

\section{Keywords}

Decision making, uncertain situations, Agriculture sector

Article Info

\section{Accepted:}

12 April 2021 Available Online: 10 May 2021
One of the most well-known and feared concepts in the world today are risk which is the product of uncertainty. Agriculture is a complicated human activity involving uncertainty and change in day to day activities. There is a need for system thinking considering agriculture with a sense of its complex wholesomeness and to take active and feasible action as many farmers are suffering with such situations. Famer experiences the impact of profit or loss as per his attitude and actual nature of his mental status This study is taken up to provide the best decision among several choices even at uncertain conditions instead the farmer's vague and random choices to achieve better profits. The study suggested that Paddy is the best option if the famer is pessimist whereas Red gram will be better choice if the farmer is optimistic in nature. Sesame is the best if he critically suffered with previous fluctuated instances. But Groundnut is a fetching crop for the farmer who is ready to accept risk despite profits.

\section{Introduction}

The uncertainty is an inevitable situation in every aspect of human life and also obviously expressed in agriculture sector. The terms 'risk' and 'uncertainty' can be defined in various ways. One common difference is to suggest that risk is imperfect knowledge where the probabilities of the possible outcomes are known whereas uncertainty exists when these probabilities are not known.
Ahuja (2010) also defined risk as a situation which the outcome of a decision is uncertain, but the probability of each possible outcome is known and can be estimated. Decision making at uncertain situations became a big challenge that leads to unexpected outcomes or losses.

In agriculture sector, a cropping pattern or allocation of land to various crops differ from farmer to famer. From the farmers perspective, profit is an objective that also be at maximum 
possible extent. Bowden et al., (1985) explained the research paradigm for system agriculture as the agriculture was a complicated human activity involving uncertainty and change. There is a need for system thinking considering agriculture with a sense of its complex wholesomeness and to take active and feasible action. According to them, Farming System Research was primarily concerned with the adoption of existing agricultural research to provide technology, relevant to farm resources. So challenges such as allocation of land for various crops, production maximization, profit maximization, minimization of cost of cultivation need to be addressed in agricultural management system. With the occurrence of uncertainty in real time situations some sort of complexity is embedded in the agricultural planning and management. Thus, there is need of scientific alternatives to handle this complex scenario of decision-making as the fetching maximization production cannot guarantee the maximum profits. Generally, in the agriculture sector, profit or loss are influenced by demand, supply, price of a crop, cost of cultivation etc...Hence the maximization of profit became a multiobjective decision-making problem with unstable choices. Agricultural production is biological in nature and highly depends on agro-climatic conditions and is being carried out in small or medium sized farms. Therefore, the farmer must make decisions in extremely unstable and insecure circumstances (Nieuwoudt, 1972). Hence this study is taken up to give some hope and scope for the farming community. With decisions under uncertainty occur agroclimatic conditions (favorable/moderately favorable/unfavorable), market price (good/average/poor), production (high/average/low) and pest instances (high/average/low))...etc. In decision making under uncertainty individual decision maker (farmer) has to choose one among a set of alternatives with complete information about their outcomes but in the absence of any information or probabilities of the various states occurance. In this juncture a real time study is taken up to with an objective of providing the best choice of crop among several alternatives even in uncertain situations of production and price using the methods indicated in methodology section as per the attitude of the famer.

Sahin et al., (2008) determine the cattle fattening breed, which maximizes the net profit for the producers under risk and uncertainties. The Wald's, Hurwicz's, Maximax, Savage's, Laplace's and Utility criterions were used. On the other hand, the decision on which crops to include in crop rotation is one of the most important decisions in field crop farm management. Agronomic, economic and market information about each individual crop constitutes an informative basis for decision-making. There is a significant amount of valuable agronomic and market information already available on main crop production, including oil crops (Rozman et al., 2006). However, the potential for a wider range of alternative crops, including oil pumpkin (Bavec and Bavec, 2006), should be evaluated in order to determine their breakcrop characteristics and the benefits and challenges which they bring to systems (Robson et al., 2002). According to Lampkin and Measures (1999), the economics of oil pumpkin depends on market price, therefore enquires with potential buyers should be undertaken. However, recent farm management research has also shown oil pumpkin production can be financially feasible assuming that the pumpkin oil can be successfully sold. Pazek (2003) and Pazek et al., (2005) conducted a financial and economic analysis of farm product processing on Slovene farms using a simulation modelling approach that included also pumpkin oil production. In agriculture there is a lack of studies that observe the application 
of criteria in the situation under uncertainness through it provides better solution at the stage of confusion in planning. Srinivasraju et al., (2000) studied on optimum cropping pattern for Sriramsagar project with an objective of maximization of net benefits. Uncertainty in the inflows arising out in the uncertainty in the rainfall is tackled through chance stochastic programming. Inflows at 4 levels of dependability viz., $75 \%, 80 \%, 85 \%$ and $90 \%$ were considered in this study to obtain various possible optimal cropping patterns and optimal operating policies. Results indicated that for $90 \%$ dependability level, paddy 450 (summer) and paddy (winter) occupied 62,930 ha and 14,700 ha area, respectively.

\section{Materials and Methods}

There are five main classical decision approaches commonly used in decision making under uncertainty to attain a better plan of action as mentioned below

Let $\mathrm{S}$ - the set of crops or decision alternatives or strategies $S_{i}($ for $i=1,2, \ldots, m)$.

E - the set of situations or events $E_{j}$ (for $j=1$, $2, \ldots, n)$

$\mathrm{R}$ - the set of payoffs (net returns) $\mathrm{R}_{\mathrm{ij}}$ obtained by choosing cropS $S_{i}$ if state $E_{j}$ occurs.

Wald's Maximin criterion (if the farmer is pessimistic)

Maximin criterion $=\operatorname{Max}\left(\min \mathrm{R}_{\mathrm{ij}}\right)$

Maximax criterion (if the farmer is optimistic) Maximax criterion $=$ Max $(\max$ $\left.\mathbf{R}_{\mathrm{ij}}\right)$

Hurwicz's criterion (weighted averages of the optimistic and pessimistic approaches with weight of $\alpha$ for optimistic plan) and find Hurwicz weighted average as $\mathrm{Hi}$;
$\mathrm{H}_{\mathrm{i}}=\alpha$ (row maximum) $+(1-\alpha)$ (row minimum) - for positive-flow payoffs (profits, revenues)

$\mathrm{H}_{\mathrm{i}}=\alpha$ (row minimum) $+(1-\alpha)$ (row maximum) - for negative-flow payoffs (costs, losses)

Find the Best strategy with Max \{ Hi $\}$ for positive-flow payoffs, and Min \{ $\mathrm{Hi}\}$ for negative-flow payoffs).

Savage's minimax regret criterion (opportunity cost or loss).

Minimax Regret decision rule is defined as:

Convert the payoff matrix $R=\left\{R_{i j}\right\}$ into an opportunity loss matrix $\mathrm{OL}=\left\{\mathrm{OL}_{\mathrm{ij}}\right\}$.

Apply the minimax rule to the OL matrix.

where,

$\mathrm{OL}_{\mathrm{ij}}=($ column $\mathrm{j}$ maximum payoff $)-\mathrm{R}_{\mathrm{ij}}$ - for positive-flow payoffs (profits, income)

$\mathrm{OL}_{\mathrm{ij}}=\mathrm{R}_{\mathrm{ij}}$ - (column $\mathrm{j}$ minimum payoff) - for negative-flow payoffs (costs)

Where $R_{i j}$ is the payoff (reward) for row $i$ and column $\mathrm{j}$ of the payoff matrix $\mathrm{R}$.

Opportunity losses are defined as nonnegative numbers. The best possible OL is zero (no regret), and the higher OL value, the greater the regret.

Laplace's insufficient reason criterion. (Equally likely occurrences of various events)

Assign $\mathrm{p}_{\mathrm{j}}=\mathrm{P}\left(\mathrm{E}_{\mathrm{j}}\right)=1 / n$ to each $\mathrm{E}_{\mathrm{j}}$ in $\mathrm{S}$, for $\mathrm{j}=$ $1,2, \ldots, \mathrm{n}$. 
For each $\mathrm{S}_{\mathrm{i}}$ (payoff matrix row), compute its expected value: $E\left(S_{i}\right)=\Sigma p_{j}\left(R_{i j}\right)$, for $i=1$, $2, \ldots, \mathrm{m}$. Since $\mathrm{p}_{\mathrm{j}}$ is a constant in Laplace, $\mathrm{E}$ $(\mathrm{Si})=\Sigma \mathrm{p}_{\mathrm{j}}\left(\mathrm{R}_{\mathrm{ij}}\right)=\mathrm{p}_{\mathrm{j}} \Sigma \mathrm{R}_{\mathrm{ij}}$.

Select the action alternative with the best $\mathrm{E}$ (Si) as the optimal decision. "Best" means max for positive-flow payoffs (profits, revenues) and min for negative-flow payoffs (costs)

\section{Results and Discussion}

\section{Problem description}

A real time data from a progressive farmer, who has 40 acres of land; 30 years of farming experience and who has been cultivating multiple crops viz., groundnut, paddy, sunflower, red gram, Bengal gram, black gram and sesame since many years, from Kalasapadu mandal of YSR Kadapa district in the southern zone of Andhra Pradesh. He faced many challenges with fluctuated prices and uncertain yields due to many uncontrollable factors.

Out of his experience, the profit achieved at four situations with a combination of yield and price viz., good yield and high market price; good yield and low market price; poor yield and high market price; poor yield and low market price, for eight crops are collected and furnished in table-4.1.

He wanted to select a best crop among eight crops to grow in forth coming season to get a very good and optimum profit even in the stage unpredictable prices and yield that means uncertainty exists in the situations.

\section{Optimum Solution}

\section{Crops (Strategies)}

S1 :Groundnut

S2 :Paddy

S3 :Sunflower

S4 :Redgram

S5 :Bengalgram

S6 :Blackgram

S7 :Cotton

S8 :Sesame

Table.1 Net profit ('000) incurred by farmer for eight crops in four situations

\begin{tabular}{|c|c|c|c|c|}
\hline \multirow{2}{*}{ Crops } & \multicolumn{4}{|c|}{ Profit in ('000) rupees at four situations } \\
\cline { 2 - 5 } & $\begin{array}{c}\text { Good yield and } \\
\text { high market } \\
\text { price }\end{array}$ & $\begin{array}{c}\text { Good yield } \\
\text { and low } \\
\text { market price }\end{array}$ & $\begin{array}{c}\text { Poor yield and } \\
\text { high market } \\
\text { price }\end{array}$ & $\begin{array}{c}\text { Poor yield } \\
\text { and low } \\
\text { market price }\end{array}$ \\
\hline Groundnut & 71.0 & 31.0 & -4.0 & -12.8 \\
\hline Paddy & 44.8 & 8.8 & 12.4 & -5.6 \\
\hline Sunflower & 50.0 & 8.0 & 6.0 & -8.0 \\
\hline Redgram & 72.0 & 5.5 & 9.0 & -7.6 \\
\hline Bengalgram & 48.0 & 6.0 & 4.0 & -10.0 \\
\hline Blackgram & 65.0 & 13.0 & 1.0 & -9.4 \\
\hline Cotton & 33.0 & 3.0 & -5.5 & -14.5 \\
\hline Sesame & 30.0 & 1.2 & 2.0 & -6.6 \\
\hline
\end{tabular}


Table.2 Expected Monetary Value for eight crops under four situations

\begin{tabular}{|c|c|c|c|c|c|c|c|}
\hline \multirow{2}{*}{$\begin{array}{c}\text { Strategies } \\
\text { (Crops) }\end{array}$} & \multicolumn{4}{|c|}{ Events (possible situations) } & \multirow{2}{*}{$\begin{array}{c}\text { 1- } \alpha=\mathbf{0 . 6} \\
\text { Min } \\
\text { payoff } \\
\text { (mi) }\end{array}$} & \multirow{2}{*}{$\begin{array}{c}\boldsymbol{\alpha}=\mathbf{0 . 4} \\
\text { Max } \\
\text { payoff } \\
(\mathrm{Mi})\end{array}$} & \multirow{2}{*}{$\begin{array}{c}\mathbf{H i}= \\
\alpha \mathbf{M i}+(1- \\
\alpha) m i\end{array}$} \\
\hline & $\begin{array}{c}\text { E1 } \\
(\mathrm{GH})\end{array}$ & E2(GL) & E3(PH) & $\mathrm{E} 4(\mathrm{PL})$ & & & \\
\hline S1:Groundnut & 71.0 & 31.0 & -4.0 & -12.8 & -12.8 & 71.0 & 20.8 \\
\hline S2:Paddy & 44.8 & 8.8 & 12.4 & -5.6 & -5.6 & 44.8 & 14.6 \\
\hline S3:Sunflower & 50.0 & 8.0 & 6.0 & -8.0 & -8.0 & 50.0 & 15.2 \\
\hline S4:Redgram & 72.0 & 5.5 & 9.0 & -7.6 & -7.6 & 72.0 & 24.2 \\
\hline S5:Bengalgram & 48.0 & 6.0 & 4.0 & -10.0 & -10.0 & 48.0 & 13.2 \\
\hline S6:Blackgram & 65.0 & 13.0 & 1.0 & -9.4 & -9.4 & 65.0 & 20.4 \\
\hline S7:Cotton & 33.0 & 3.0 & -5.5 & -14.5 & -14.5 & 33.0 & 4.5 \\
\hline S8: Sesame & 30.0 & 1.2 & 2.0 & -6.6 & -6.6 & 30.0 & 8.0 \\
\hline
\end{tabular}

Table.3 Regret matrix or opportunity loss matrix

\begin{tabular}{|c|c|c|c|c|c|}
\hline \multirow{2}{*}{$\begin{array}{c}\text { Strategies } \\
\text { (Crops) }\end{array}$} & \multicolumn{4}{|c|}{ Events (possible situations) } & Maximum \\
\cline { 2 - 5 } & E1(GH) & E2(GL) & E3(PH) & E4(PL) & Regrets \\
\hline S1:Groundnut & 0 & 40.0 & 75.0 & 83.8 & 83.8 \\
\hline S2:Paddy & 0 & 36.0 & 32.4 & 50.4 & 50.4 \\
\hline S3:Sunflower & 0 & 42.0 & 44.0 & 58.0 & 58.0 \\
\hline S4:Redgram & 0 & 66.5 & 63.0 & 79.6 & 79.6 \\
\hline S5:Bengalgram & 0 & 42.0 & 44.0 & 58.0 & 58.0 \\
\hline S6:Blackgram & 0 & 52.0 & 64.0 & 74.4 & 74.4 \\
\hline S7:Cotton & 0 & 30.0 & 38.5 & 47.5 & 47.5 \\
\hline S8: Sesame & 0 & 28.8 & 28.0 & 36.6 & 36.6 \\
\hline
\end{tabular}

Table.4

\begin{tabular}{|c|c|c|c|c|c|c|}
\hline \multirow{2}{*}{$\begin{array}{c}\text { Strategies } \\
\text { (Crops) }\end{array}$} & \multicolumn{4}{|c|}{ Events } & \multirow[t]{2}{*}{ Total } & \multirow[t]{2}{*}{$\mathbf{E}(\mathbf{S i})$} \\
\hline & $\begin{array}{c}\mathrm{E} 1(\mathrm{GH}) \\
(1 / 4=0.25)\end{array}$ & $\begin{array}{c}\text { E2(GL) } \\
(1 / 4=0.25)\end{array}$ & $\begin{array}{c}\text { E3(PH) } \\
(1 / 4=0.25)\end{array}$ & $\begin{array}{c}\mathrm{E} 4(\mathrm{PL}) \\
(1 / 4=0.25)\end{array}$ & & \\
\hline S1:Groundnut & 71.0 & 31.0 & -4.0 & -12.8 & 85.2 & 21.3 \\
\hline S2:Paddy & 44.8 & 8.8 & 12.4 & -5.6 & 60.4 & 15.1 \\
\hline S3:Sunflower & 50.0 & 8.0 & 6.0 & -8.0 & 56.0 & 14.0 \\
\hline S4:Redgram & 72.0 & 5.5 & 9.0 & -7.6 & 78.9 & 19.7 \\
\hline S5:Bengalgram & 48.0 & 6.0 & 4.0 & -10.0 & 48.0 & 12.0 \\
\hline S6:Blackgram & 65.0 & 13.0 & 1.0 & -9.4 & 69.6 & 17.4 \\
\hline S7:Cotton & 33.0 & 3.0 & -5.5 & -14.5 & 16.0 & 4.0 \\
\hline S8: Sesame & 30.0 & 1.2 & 2.0 & -6.6 & 26.6 & 6.7 \\
\hline
\end{tabular}




\section{Possible situations (Events)}

E1(GH) : Good yields and High market price

E1(GL) : Good yields and Low market price

E1(PH) : Poor yields and High market price

E1(PH) : Poor yields and Low market price

\section{Wald's Maximin criterion}

$\operatorname{Max}(\min$ Payoffs $)=\operatorname{Max}(-12.8,-5.6,-8.0$, $7.6,-10.0,-9.4,-14.5,-6.6)=-5.6$

Hence the best strategy is S2 i.e, Paddy

\section{Maximax criterion}

$\operatorname{Max}(\max$ Payoffs $)=\operatorname{Max}(71.0,44.8,50.0$, $72.0,48.0,65.0,33.0,30.0)=72.0$

Hence the best strategy is S4 i.e Redgram

$\begin{array}{lcc}\begin{array}{l}\text { Hurwicz } \\ \text { alpha=0.4 }\end{array} & \text { alpha criterion } & \text { assuming } \\ & & \\ \operatorname{Max} \quad\left(\mathrm{EMV}_{\mathrm{i}}\right) & = & \operatorname{Max} \\ (20.8,14.6,15.2,24.2,13.2,20.4,4.5,8.0) & =24.2\end{array}$

Hence the bests trategy is S4 i.e Redgram

\section{Savage's minimax Regret criteria}

Minimax Regrets $=$ Min (maximum regrets)

$=\operatorname{Min}(83.8,50.4,58.0,79.6,58.0,74.4,47.5$, $36.6)=36.6$

Hence the best strategy is S8 i.e Sesame

Laplace criteria(consider equal probability i.e $1 / 4$ for each event (since there are four events) $\operatorname{Max}\left(\mathrm{E}\left(\mathrm{S}_{\mathrm{i}}\right)\right)=\operatorname{Max}(21.3,15.1,14.0,19.7$, $12.0,17.4,4.0,6.7)=21.3$
Hence the best strategy is S1 i.e Groundnut From this study it can be identified that if there is no any evidential support to estimate the expected yields and market prices in real time situations the best choice of crops can be identified even at uncertain conditions to maximize profits using various methods as explained below as per the data

Through Wald's Maximin criteria the best strategy is $\mathrm{S}_{2}$ i.ePaddy if the famer is pessimist.

Maximax criteria identified $\mathrm{S}_{4}$ as the best strategy i.e Redgram if the farmer is optimist.

With the help of Hurwicz alpha criterion (assuming alpha=0.4) the best strategy is $\mathrm{S}_{4}$ i.e Redgram if the farmer is neither pessimist nor optimist.

S8i.e, Sesame is identified as the best crop if the farmer is risk avert by the Savage's minimax regret criteria.

Laplace criteria suggests $\mathrm{S}_{1}$ as the best strategie i.e Groundnut if the famer is risk bearer.

\section{References}

Ahuja, H. L. 2010. Advanced Microeconomic Analysis, 17th edition. S. Chand and Company Ltd.

Bavec, F., Bavec, M. (2006): Organic production and use of alternative crops, (Books in soils, plants, and the environment, 116). Boca Raton; New York; London: Taylor \& Francis: CRC Press, $241 \mathrm{pp}$.

Lampkin N., Measures, M. (1999): Organic farm management handbook - 3rd Edition, University of Wales, Aberystwyth, Elm farm research centre. 163 pp. 
Nieuwoudt, W. L. 1972. Risk and uncertainty in agriculture. Agricultural Economics Research, Policy and Practice in Southern Africa, 11(2): 20-25.

Pazek, K. (2003): The financial analysis of supplementary activities on organic farms. M.Sc Thesis, University of Maribor, Faculty of Agriculture). 168 pp.

Pazek, K., Rozman, Č., Turk, J., Bavec, M., Pavlovič, M. (2005.): EinSimulations modell für Investitions analyse der Nahrungsmittelverarbeitung auf ökologischenBetrieben in Slowenien. Bodenkultur 56(2):121.-131.

Robson, M. C., Fower, S. M. Lampkin, N. H., Leifert, C., Leitch, M., Robinson, D., Watson, C. A., Litterick, A. M. (2002): The agronomic and economic potential of break crops for ley/arable rotations in temperate organic agriculture. Advances in Agronomy, 77: 369-427.

Rozman, Č., Pažek, K., Bavec, M., Bavec, F., Turk, J., Majkovič, D. (2006): The Multi-criteria analysis of spelt food processing alternatives on small organic farms. J. Sustain. Agric. 28(2):159-179.

Sahin, A., Miran, B., Yildirim, I., Onenc, A. (2008): Profit Maximization of Cattle Fattening Breed Based on Characteristics of Producers: An Application of Game Theory. Journal of Animal and Veterinary Advances, 7(10):1305-1309.

Srinivasa Raju, K. and Nagesh Kumar, D. 2000. Optimum cropping pattern for Sri Ram Sagar Project: A linear programming approach, Journal of Applied Hydrology, 8: 57-67.

\section{How to cite this article:}

Lavanya Kumari, P. and Maheswara Reddy, P. 2021. Decision Making under Uncertainty in Agriculture- A case study. Int.J.Curr.Microbiol.App.Sci. 10(05): 188-194.

doi: https://doi.org/10.20546/ijcmas.2021.1005.025 